\title{
TINJAUAN YURIDIS TERHADAP PEMILIHAN GUBERNUR DAN WAKIL GUBERNUR DALAM SISTEM PEMERINTAHAN DAERAH DI INDONESIA
}

\author{
Muhammad Andi Susilawan \\ Fakultas Hukum Universitas Riau \\ Email:mas.andi26@yahoo.co.id \\ Ikhsan dan Dodi Haryono \\ Fakultas Hukum Universitas Riau
}

\begin{abstract}
Election of Governor and Deputy Governor in Law Number 32 of 2004 which is elected directly by the people. From the results of this study concluded that there are several principles. First, the background is applied to the election of the governor and vice governor directly in Law Number 32 of 2004 on Regional Government, philosophically motivated to carry out direct elections is partly due to indirect mechanisms of democracy does not guarantee accommodation in choosing future leaders. Second, the strengths and weaknesses of the election for governor and vice governor directly in Law Number 32 of 2004 on Regional Government, the benefits are local elections in person an opportunity for political education, the system of checks and balances between the legislative and executive more balanced, as a means to strengthen regional autonomy. As for the cost of the funds needed in the election for governor and lieutenant governor are relatively higher, opening the possibility of conflict and elite, activities of people with disabilities, especially during the campaign. Thirdly, it is necessary to correct weaknesses gubernatorial election in accordance with the development of local government is currently increasing citizens political awareness, empowerment of the governor and deputy governor are direct, general, free, confidential, honest, and fair. election of governors and vicegovernors enforcement of financial restrictions consistent and campaigns.
\end{abstract}

Keywords: Election of Governor and Deputy Governor, Local Government

\section{abstrak}

Pemilihan Gubernur dan Wakil Gubernur dalam UU Nomor 32 Tahun 2004 yang dipilih secara langsung oleh rakyat. Dari hasil penelitian ini disimpulkan bahwa terdapat beberapa prinsip. Pertama, latar belakang diterapkan pada pemilihan gubernur dan wakil gubernur secara langsung dalam UU Nomor 32 Tahun 2004 tentang Pemerintahan Daerah, secara filosofis motivasi untuk melaksanakan pemilihan langsung ini antara lain karena mekanisme tidak langsung demokrasi tidak menjamin akomodasi 
dalam memilih calon pemimpin. Kedua, kekuatan dan kelemahan dari pemilihan gubernur dan wakil gubernur secara langsung di Undang-Undang Nomor 32 Tahun 2004 tentang Pemerintahan Daerah, keuntungan yang diperoleh adalah pemilihan kepala daerah secara langsung merupakan kesempatan bagi pendidikan politik rakyat, sistem check and balance antara legislatif dan eksekutif dapat lebih seimbang, sebagai sarana untuk memperkuat otonomi daerah. Adapun biaya dana yang dibutuhkan dalam pemilihan gubernur dan wakil gubernur yang relatif lebih tinggi, membuka kemungkinan konflik dan elit, kegiatan orang-orang cacat khususnya selama kampanye. Ketiga, diperlukan upaya untuk memperbaiki kelemahan pemilihan gubernur dan wakil gubernur sesuai dengan perkembangan pemerintah daerah saat ini meningkat warga kesadaran politik, pemberdayaan gubernur dan wakil gubernur yang langsung, umum, bebas, rahasia, jujur, dan adil. pemilihan penegakan gubernur dan wakil gubernur pembatasan keuangan yang konsisten dan kampanye.

Kata Kunci: Pemilihan Gubernur dan Wakil Gubernur, Pemerintah Daerah

\section{A. Pendahuluan}

Sistem pemilihan kepala daerah (gubernur, bupati/walikota) merupakan perjalanan politik yang panjang yang diwarnai tarik menarik antara kepentingan elit politik dan kehendak publik, kepentingan pusat dan daerah, atau bahkan antara kepentingan nasional dan internasional. ${ }^{1}$ berdasarkan sejarah pemerintahan Indonesia sejak proklamasi kemerdekaan Republik Indonesia pada tanggal 17 Agustus 1945, merancang UndangUndang Dasar (UUD) yang didalamnya mengatur secara eksplisit tentang Pemerintahan Daerah. ${ }^{2}$

Berdasarkan Undang-Undang Dasar Negara Republik Indonesia Tahun 1945 Pasal 18 ayat (1) bahwa,

"Pemerintahan Daerah yang dimaksud adalah Kesatuan Negara Republik Indonesia yang dibagi atas daerah-daerah provinsi dan daerah provinsi itu dibagi atas kabupaten dan kota, yang tiap-tiap provinsi, kabupaten, dan kota itu mempunyai pemerintahan daerah, yang diatur di dalam undang-undang. Masing-masing pemerintahan daerah dipimpin oleh kepala daerah, baik di tingkat daerah provinsi maupun daerah kabupaten/kota. Berdasarkan Undang-Undang Nomor 32 Tahun 2004 Pasal 24 ayat (2) tentang Pemerintahan Daerah "yang mana kepala daerah sebagaimana

\footnotetext{
${ }^{1}$ Suharizal, Pemilukada Regulasi Dinamika, dan Konsep mendatang, (Jakarta: Raja Grafindo Persada, 2011), hlm. 15.

${ }^{2}$ Ibid.
} 
dimaksud pada ayat (1) untuk provinsi disebut Gubernur, untuk kabupaten disebut Bupati, dan untuk kota disebut Walikota".

Undang-undang yang mengatur tentang pemerintahan daerah terdapat beberapa pasal tentang pemilihan kepala daerah dan wakil kepala daerah baik dari awal kemerdekaan Indonesia hingga saat ini. Adapun beberapa aturan di dalam sejumlah undang-undang tentang pemerintahan daerah di Indonesia, yaitu Undang-Undang Nomor 1 Tahun 1945, Undang-Undang Nomor 22 Tahun 1948, Undang-Undang Nomor 1 Tahun 1957, UndangUndang Nomor 18 Tahun 1965, Undang-Undang Nomor 5 Tahun 1974, Undang-Undang 22 Tahun 1999, Undang-Undang Nomor 32 Tahun 2004, dan Undang-Undang Nomor 12 Tahun 2008.

Negara Indonesia berdasarkan Undang-Undang Nomor 32 Tahun 2004 tentang Pemerintahan Daerah didalamnya diatur secara jelas mengenai pelaksanaan pemilihan kepala daerah dan wakil kepala daerah secara langsung oleh rakyat yang dilaksanakan secara demokratis berdasarkan asas langsung, umum, bebas, jujur, dan adil. Pemilihan secara langsung adalah jelas di mana rakyat sebagai pemilih mempunyai hak untuk memberikan suaranya. ${ }^{3}$ Ini adalah merupakan imbas dari semangat di dalam otonomi kedaerahan, di mana titik poin penting yang kita simpulkan terhadap Undang-Undang Nomor 32 Tahun 2004 adalah dipilihnya kepala daerah dan wakil kepala daerah secara langsung oleh rakyat.

Akhir-akhir ini di tingkat pemerintahan pusat antara Dewan Perwakilan Rakyat (DPR) dengan pemerintah terjadi perdebatan ilmiah terhadap pemilihan kepala daerah di tingkat provinsi yang tidak melibatkan rakyat langsung kembali di dalam draft Rancangan Undang-Undang (RUU) pemilukada. Menurut Menteri Dalam Negeri Gamawan Fauzi, seorang kepala daerah dan wakil kepala daerah tingkat provinsi yaitu gubernur dan wakil gubernur untuk dipilih langsung oleh rakyat menjadi tidak relevan karena interaksi yang terjalin antar rakyat dan seorang gubernur juga tidak langsung. Oleh karena itu, mekanisme pemilihan yang paling kompatibel untuk diterapkan dalam pemilihan gubernur adalah dengan mekanisme perwakilan yang di dalam hal ini dipilih dalam melalui suara terbanyak oleh Dewan Perwakilan Rakyat Daerah Provinsi (DPRD) yang bersangkutan. ${ }^{4}$ Jadi dalam Rancangan Undang-Undang (RUU) yang merevisi tentang Pemerintahan Daerah, di mana gubernur dipilih oleh dewan perwakilan rakyat daerah provinsi, hanya bupati atau walikota saja yang dipilih langsung oleh rakyat.

3 http://www.PolitikIndonesia.com/m/index.php?ctn=politik\&i=29840. (Terakhir diakses Sabtu 15 Desember2012).

4 http://www.Adeksi.or.id/Detail_Berita.php?no=226, (Terakhir diakses Rabu, 18 Oktober 2012). 
Perlu dipahami, sejauh ini praktek yang terjadi dilapangan terhadap pemilihan kepala daerah (baik gubernur, bupati, dan walikota) yang dipilih langsung oleh rakyat banyak sekali menimbulkan kerugian-kerugian yang signifikan. Kerugian-kerugian tersebut diantaranya banyak masyarakat cenderung bersifat euphoria dan fanatisme terhadap calon yang mereka usung sehingga sangat memungkinkan untuk melakukan tindakan-tindakan melanggar aturan demi memenangkan pasangan calon pemimpin yang mereka usung. Bahkan, apabila calon yang mereka usung gagal memenangkan perhelatan pemilukada, maka bukan tidak mungkin massa pendukung masing-masing akan melakukan tindakan kriminal dengancara bentrok antara massa pendukung yang mengakibatkan rusaknya fasilitas umum, dengan membakar tempat peribadahan yang terjadi pada pemilukada Bupati dan Wakil Bupati Kuantan Singingi, Riau, yang tidak puas dengan hasil penghitungan suara pemilukada. Bahkan yang lebih parah dengan cara membakar rumah pribadi pasangan yang memenangkan pemilukada (contoh kasus pada Pemilihan Gubernur dan Wakil Gubernur Papua Barat antara Abraham O Ataruri dan yang kalah Dominggus Mandacan-Origenes Nauw, 15 Desember 2011). ${ }^{5}$ Kemudian apabila kita tinjau dari segi pendanaan bahwa pemilihan langsung gubernur dan wakil gubernur cenderung lebih banyak memakan biaya negara dalam APBN, apalagi dilakukan pemilihan dengan dua kali putaran jikalau tidak selesai dengan pemilihan satu putaran.

Sebaliknya pendapat yang berlawanan menyebutkan, jikalau Rancangan Undang-Undang (RUU) Pemilukada yang telah dibuat oleh pemerintah tersebut dilaksanakan dan diterapkan dalam sistem pemilihan kepala derah dan wakil kepala daerah tingkat provinsi yaitu gubernur dan wakil gubernur maka ini merupakan salah satu bentuk kemunduran demokrasi didalam sistem pemerintahan daerah, yaitu ditandai dengan tidak melibatkannya kembali masyarakat di dalam memberikan suaranya terhadap pemilihan kepala daerah dan wakil kepala daerah tingkat provinsi. Pendapat tersebut senada dengan apa yang disampaikan oleh Saldi Isra bahwa sistem pemilihan kepala daerah dan wakil kepala daerah langsung oleh rakyat adalah salah satu bentuk memberikan pendidikan politik serta pendewasaan masyarakat didalam partisipasi politik. Hal ini cenderung sulit terwujudkan apabila rakyat tidak dilibatkan langsung di dalam proses pemilihan kepala daerah dan wakil kepala daerah tingkat provinsi. Lain daripada itu, tidak ada jaminan politik bersih apabila pemilihan kepala daerah dan wakil kepala daerah tingkat provinsi ketika dipilih kembali oleh Dewan Perwakilan Rakyat Daerah (DPRD).

\footnotetext{
${ }^{5}$ http://www.PolitikIndonesia.com/m/index.php?ctn=politik\&i=29840. (Terakhir diakses Sabtu 15 Desember2012).
} 
Dari penjelasan tersebut tentunya menarik sekali untuk mengetahui pertanyaan bagi kita terhadap penerapan sistem pemilihan gubernur dan wakil gubernur secara langsung. Apakah sistem pemilihan secara langsung gubernur dan wakil gubernur berdasarkan Undang-Undang Nomor 32 Tahun 2004 tentang Pemerintahan Daerah relevan dengan perkembangan daerah saat sekarang ini. Pertama, bagaimanakah latar belakang diterapkannya pemilihan gubernur dan wakil gubernur secara langsung dalam UndangUndang Nomor 32 Tahun 2004 tentang Pemerintahan Daerah? kedua, apa kelebihan dan kelemahan pemilihan gubernur dan wakil gubernur secara langsung di dalam Undang-Undang Nomor 32 Tahun 2004 tentang Pemerintahan Daerah di Indonesia?; dan ketiga, upaya apakah yang perlu dilakukan untuk memperbaiki kelemahan pemilihan gubernur dan wakil gubernur yang sesuai dengan perkembangan pemerintahan daerah saat ini?

\section{B. Pembahasan}

Gagasan pemilihan kepala daerah secara langsung muncul akibat kebijakan desentralisasi luas yang dicanangkan melalui Undang-Undang Nomor 22 Tahun 1999 yang semestinya ditunjukan untuk memperbaiki iklim demokrasi, dinilai belum cukup memberi peluang bagi berkembangnya partisipasi masyarakat terhadap proses kebijakan publik daerah. Pelaksanaan Undang-Undang Nomor 22 Tahun 1999 tersebut banyak ditafsirkan secara sempit oleh para penyelenggara pemerintahan didaerah bahwa otonomi ada ditangan pemerintahan daerah bukan pada rakyat di daerah. Akibatnya muncul gagasan tentang perlunya pemilu dan parpol lokal sebagai instrumen demokrasi yang memang sama sekali tidak diatur dalam Undang-Undang Nomor 22 Tahun 1999 tersebut. Pemilihan kepala daerah secara langsung sebenarnya dapat dikatakan sebagai terobosan yang sangat besar dan berani karena banyak persoalan yang sebenarnya harus dipersiapkan terhadap pemilihan kepala daerah secara langsung sebelum hal itu diberlakukan. Harus dipahami bahwa secara psikologis ide tersebut timbul dengan penerapan perpolitikan secara langsung didaerah adalah merupakan bentuk dari ketidakpercayaan masyarakat terhadap keberadaan politik nasional sehingga yang lebih diharapkan adalah munculnya partai lokal yang bukan merupakan kepanjangan tangan dari partai-partai tingkat nasional. Dinamika dan heterogenitas lokal yang mencerminkan aspirasi riil didaerah akan lebih terakomodir dengan keberadaan partai-partai lokal yang lebih independen. ${ }^{6}$

\footnotetext{
${ }^{6}$ Agus Pramusinto, Erwan Agus Purwantodk, Reformasi Birokrasi, Kepemimpinan dan Pelayanan Publik Kajian tentang pelaksanaan otonomi Daerah di Indoensia, (Yogyakarta: Gava Media, 2009), hlm.184.
} 


\section{Latar Belakang Diterapkannya Pemilihan Gubernur dan Wakil Gubernur Secara Langsung dalam Undang-undang Nomor 32 Tahun 2004 tentang Pemerintahan Daerah}

Adapun beberapa sebab diterapkannya pemilihan kepala daerah dalam hal ini gubernur dan wakil gubernur secara langsung dalam Undang-Undang Nomor 32 Tahun 2004 ada 3 tinjauan:

\section{a. Tinjauan Filosofis}

Secara filosofis kita bisa melihat bahwa memang pemberlakuan untuk menerapkan demokrasi politik secara langsung di daerah hal ini terjadi akibat bentuk dari ketidakpercayaan masyarakat terhadap keberadaan politik nasional sehingga yang lebih diharapkan adalah munculnya partai lokal yang bukan merupakan kepanjangan tangan dari partai-partai tingkat nasional. Selain itu, hal ini merupakan salah satu langkah maju dalam kebijakan desentralisasi dan proses demokratisasi di Indonesia. Dorongan untuk melaksanakan pemilihan kepala daerah secara langsung ini antara lain karena mekanisme demokrasi secara tidak langsung belum menjamin terakomodasinya aspirasi rakyat dalam memilih calon pemimpinnya. Mekanisme pemilihan kepala daerah tidak langsung hanya menguntungkan sekelompok elit politik yang berorentasi pada kepetingan jangka pendek. Perlu kita cermati, berdasarkan Undang-Undang Nomor 32 tahun 2004, kita dapat membahas adanya perkembangan demokrasi yang semakin dekat dengan konstituennya yaitu masyarakatnya. Secara umum ini merupakan kemajuan yang sangat berarti bagi hubungan pemerintahan daerah dengan rakyatnya dalam hal penggunaan hak politiknya.

Selanjutnya pemilukada langsung ini bisa dilihat dari adanya legitimasi elit eksekutif lokal terpilih berkaitan dengan dukungan rakyat daerah kepadanya yang sebanding dengan pemilu legislatif daerah yang menjadi satu paket dengan pemilihan DPR dan DPD. Jadi berdasarkan aspek legitimasi, pilkada langsung merupakan salah satu keunggulan yang siginifikan. Berikutnya adalah berperannya rakyat daerah dalam menentukan langsung pilihannya, tidak mewakilkan pada DPRD seperti pada periode pemilihan kepala daerah berdasarkan Undang-Undang Nomor 22 tahun 1999. Seperti yang dijelaskan oleh penulis sebelumnya secara umum memanglah pemberian hak politik dalam menentukan elit eksekutif lokal ini merupakan keunggulan dari Undang-Undang Pemerintahan Daerah yang baru berdasarkan Undang-Undang Nomor 32 Tahun 2004.

\section{b. Tinjauan Sosiologis}

Pemilihan kepala daerah dalam hal ini gubernur dan wakil gubernur secara langsung oleh rakyat merupakan perwujudan pengembalian "hak-hak 
dasar" rakyat dalam memilih pemimpin didaerah. Dengan itu rakyat memiliki kesempatan dan kadaulatan untuk menentukan pemimpin di daerah secara langsung, bebas, dan rahasia tanpa adanya intervensi, sama seperti mereka memilih presiden dan wakil presiden dan wakil-wakilnya dilembaga legislatif (Dewan Perwakilan Rakyat/DPR, Dewan Perwakilan Daerah/DPD, Dewan Perwakilan Rakyat Daerah/DPRD).

Selanjutnya, ditinjau dari segi pendanaan yaitu untuk membatasi terjadinya politik uang dikalangan elit pemerintahan daerah, yang pada waktu pemilukada lalu bermuara pada penyelenggaranya, yaitu DPRD melalui kepanjangan tangan fraksi. Jadi, dimungkinkan melemahnya politik uang tentunya apabila dipenuhi syarat dalam pencalonan dan pemilihannya. Selain itu, juga memberikan kesan lebih yang lebih bersifat objektif. Perlibatan masyarakat dalam demokrasi dan perpolitikan daerah adalah bukan hal yang tabu lagi, sebab masyarakat sudah terbiasa dengan peran sebagai pemilih langsung dalam menentukan wakil- wakil mereka di lembaga legislatif, baik DPR, DPD, DPRD Provinsi, dan DPRD Kabupaten/kota atau bahkan pemilihan presiden dan wakil presiden di tingkat nasional.

\section{c. Tinjauan Yuridis}

Pemilukada secara langsung sesungguhnya sudah diintrodusir dalam produk hukum yang mengatur pemerintahan di daerah jauh sebelum pembentukan Undang-Undang Nomor 32 Tahun 2004 dan Undang-Undang Nomor 22 Tahun 2007. Dalam Pasal 23Undang-Undang Nomor 1 Tahun 1957 tentang Pokok-Pokok Pemerintahan Daerah ditegaskan, kepala daerah yang karena jabatannya adalah ketua dan anggota Dewan Pemerintahan Daerah (DPD) yang berfungsi menjalankan roda pemerintahan dipilih menurut Undang-Undang khusus yang akan ditetapkan kemudian. ${ }^{7}$ Pada bagian penjelasan dikatakan, ketentuan demikian karena kepala daerah adalah orang yang dekat dan dikenal baik oleh rakyat didaerahnya. Oleh karena itu, harus dipilih langsung oleh rakyat. Karena proses pembentukan Undang-Undang Nomor 1 Tahun 1957 tersebut lama, untuk sementara kepala daerah dipilih oleh DPRD yang bersangkutan, yang kemudian disahkan oleh Presiden/Menteri Dalam Negeri, sampai Undang-Undang Nomor 1 Tahun 1957 dicabut, undang-undang tentang pemilihan kepala daerah langsung tidak lahir. ${ }^{8}$ Hal ini merupakan suatu impian yang akhirnya terwujud, suatu pesta demokrasi lokal yang berfungsi untuk mencari sosok pemimpin daerah sesuai dengan yang impian dari masyarakat daerah.

\footnotetext{
${ }^{7}$ Ibid.

${ }^{8}$ Ibid.
} 
Hingga akhirnya pemilukada secara langsung oleh rakyat diterapkan berdasarkan Undang-Undang Nomor 32 Tahun 2004.

2. Kelebihan dan Kelemahan Pemilihan Gubernur dan Wakil Gubernur Secara Langsung di dalam Undang-Undang Nomor 32 Tahun 2004 tentang Pemerintahan Daerah di Indonesia

Adapun beberapa kelebihan Undang-Undang Nomor 32 Tahun 2004 tentang Pemerintahan Daerah terhadap bentuk pemilihan Gubernur dan wakil gubernur secara langsung sebagai berikut ${ }^{9}$;

\section{a. Pemilukada Langsung Merupakan Jawaban atas Tuntutan Aspirasi Rakyat}

Pemilihan presiden dan wakil presiden, DPR, DPD, bahkan kepala desa selama ini telah dilakukan secara langsung. Artinya masyarakat sudah tidak asing lagi dengan sistem demokrasi langsung dengan melibatkan rakyat dalam pemilihan. Pemilukada langsung merupakan perwujudan konstitusi dan UUD 1945. Seperti telah diamanatkan Pasal 18 Ayat (4) UUD 1945, gubernur, bupati, dan wali kota, masing-masing sebagai kepala pemerintahan daerah provinsi, kabupaten, dan kota dipilih secara demokratis. Hal ini telah diatur dalam Undang-Undang No 32 Tahun 2004 tentang Pemilihan, Pengesahan, Pengangkatan, dan Pemberhentian Kepala Daerah dan Wakil Kepala Daerah. Kepala daerah terpilih akan memiliki mandat dan legitimasi yang sangat kuat karena didukung oleh suara rakyat yang memberikan suara secara langsung. Legitimasi merupakan hal yang sangat diperlukan oleh suatu pemerintahan yang sedang mengalami krisis politik dan ekonomi.

\section{b. Check and Balances antara Lembaga Legislatif dan Eksekutif Dapat Lebih Berjalan Seimbang}

Kamus hukum mendefinisikan prinsip check and balances sebagai sebuah sistem aturan yang menegaskan adanya mekanisme saling kontrol diantara cabang kekuasaan baik legislatif, eksekutif, maupun yudikatif yang didesain untuk mencegah terkonsentrasinya kekuasaan dalam satu cabang sehingga mendominasi cabang kekuasaan yang lain. ${ }^{10}$

Secara konseptual, prinsip check and balances dimaksudkan agar tidak terjadi overlapping atau tumpang tindih antara kewenangan lembaga negara sehingga kekuasaan dalam negara haruslah diatur dengan seksama.

\footnotetext{
${ }^{9}$ http://www.Google.com/search?ie=UTF8\&Sourceid=navclient\&gfns=1\&q=Makalah + tentang+Pilkada(Terakhir diakses pada Tanggal 29 Desember 2012).

${ }^{10}$ http://masnurmarzu ki.blogspot.com/2011/12/Pemisahan-Pekuasaan-dan-Prinsip-Checks.h tml9 (Terakhir diakses Tanggal 22 Januari 2013)
} 
Dengan mendasarkan pada spektrum pelaksanaannya, prinsip checksand balances dapat diklasifikasikan menjadi dua macam yakni, pertama, pelaksanaan checks and balances internal dalam cabang kekuasaan tertentu. Kedua, adanya pelaksanaan checks and balances antara cabang-cabang kekuasaan. ${ }^{11}$ Prinsip pemisahan kekuasaan membagi tanggungjawab pemerintahan legislatif, eksekutif, dan yudikatif.

\section{c. Pemilukada Langsung Sebagai Sarana Pembelajaran Demokrasi (Politik) Bagi Rakyat}

Kesadaran akan pentingnya demokrasi sekarang ini sangat tinggi. Hal ini dapat dilihat dari peran serta rakyat Indonesia dalam melaksanakan Pemilihan Umum baik yang dilaksanakan oleh pemerintah pusat dan pemerintah daerah. Ini terlihat dari jumlah pemilih yang tidak menggunakan hak pilihnya yang sedikit. Pemilukada langsung menjadi media pembelajaran praktek berdemokrasi bagi rakyat yang diharapkan dapat membentuk kesadaran kolektif segenap unsur bangsa tentang pentingnya memilih pemimpin yang benar sesuai nuraninya. Dimana kriteria calon kepala daerah dalam hal ini gubernur dan wakil gubernur dapat dinilai secara langsung oleh rakyat yang akan memberikan suaranya.

Pemilihan kepala daerah gubernur dan wakil gubernur merupakan salah satu bentuk pendidikan politik bagi rakyat yang bersifat langsung, terbuka, dan massal yang diharapkan bisa mencerdaskan pemahaman politik dan meningkatkan kesadaran masyarakat tentang demokratis. ${ }^{12}$ Letak pendidikan politik yang dapat dirasakan oleh rakyat adalah, yaitu dengan perlibatan masyarakat dalam proses pemilukada sampai pada pemilihan untuk para calon Gubernur dan Wakil Gubernur.

\section{d. Pemilukada Langsung Sebagai Sarana Untuk Memperkuat Otonomi Daerah}

Makna Otonomi Daerah berdasarkan Pasal 1 ayat (5) Undang-Undang Nomor 32 Tahun 2004 tentang Pemerintahan Daerah, yaitu:

"Otonomi Daerah adalah hak, wewenang, dan kewajiban daerah otonom untuk mengatur dan mengurus sendiri urusan pemerintahan dan kepentingan masyarakat setempat sesuai dengan peraturan perundang-undangan".

Keberhasilan otonomi daerah salah satunya juga ditentukan oleh pemimpin lokal. Semakin baik pemimpin lokal yang dihasilkan dalam pemilukada langsung, maka komitmen pemimpin lokal dalam mewujudkan

\footnotetext{
${ }^{11}$ Ibid.

12 Jhanpatar Simamora, Eksistensi Pemilukada dalam Rangka Mewujudkan Pemerintahan Daerah yang Demokratis, Mimbar Hukum Volume 23 No. 1 Februari 2011, hlm.7.
} 
tujuan otonomi daerah, antara lain untuk meningkatkan kesejahteraan masyarakat dengan selalu memperhatikan kepentingan dan aspirasi masyarakat agar dapat diwujudkan. Di samping itu, Kepala Daerah terpilih tidak perlu terikat pada konsesnsi partai-partai atau fraksi-fraksi yang telah mencalonkannya.

\section{e. Pemilukada Langsung Merupakan Sarana Penting bagi Proses Kaderisasi Kepemimpinan Nasional}

Disadari atau tidak, stok kepemimpinan nasional amat terbatas. Dari jumlah penduduk Indonesia yang lebih dari 200 juta, jumlah pemimpin nasional yang kita miliki hanya beberapa. Mereka sebagian besar para pemimpin partai politik besar yang memenangi Pemilu 2004. Karena itu, harapan akan lahirnya pemimpin nasional justru dari pemilukada langsung ini. Pemilukada langsung adalah merupakan koreksi terhadap sistem demokrasi tidak langsung (perwakilan) di era sebelumnya, di mana kepala daerah dan wakil kepala daerah dipilih oleh DPRD, menjadi demokrasi yang berakar langsung pada pilihan rakyat (pemilih). Sistem demokrasi langsung melalui pemilukada langsung akan membuka ruang partisipasi yang lebih luas bagi warga dalam proses demokrasi dan menentukan kepemimpinan politik ditingkat lokal dibandingkan sistem demokrasi perwakilan yang lebih banyak meletakan kuasa untuk menentukan rekruitmen politik ditangan segelintir orang di DPRD (Oligarkhis).

\section{f. Pemilukada Langsung Merupakan Suatu Langkah yang Strategis dalam Rangka Memperluas, Memperdalam, dan Meningkatkan Kualitas Demokrasi}

Hal ini juga sejalan dengan semangat otonomi, yaitu pengakuan terhadap aspirasi daninisiatif masyarakat lokal (daerah) untuk menentukan nasibnya sendiri. ${ }^{13}$ Selanjutnya, sistem pemilukada langsung lebih akuntabel dibanding sistem perwakilan yang selama ini digunakan, karena rakyat tidak harus menitipkan suaranya kepada anggota legislatif atau electoral college secara sebagian atau penuh, di mana rakyat dapat menentukan pilihannya berdasarkan kepentingan dan penilaian atas calon. Apabila kepala daerah tidak memenuhi harapan masyarakat, maka dalam pemilihan berikutnya calon yang bersangkutan tidak akan dipilih kembali. Prinsip ini merupakan pengawasan serta akuntabilitas yang paling sederhana dan dapat dimengerti baik oleh rakyat maupun politisi. ${ }^{14}$

\footnotetext{
${ }^{13}$ Suharizal, Op.cit. hlm. 28.

${ }^{14}$ JokoJ. Prihatmoko, Pemilihan Kepala Daerah Langsung, Filosofi, Sistem, dan Problema

Penerapan di Indonesia, (Yogyakarta: Pustaka Pelajar, 2005), hlm. 132.
} 
Adapun beberapa kelemahan terhadap pemilihan kepala daerah (pemilukada) langsung terhadap gubernur dan wakil gubernur sebagai berikut ${ }^{15}$ :

\section{a. Dana yang Dibutuhkan dalam Penyelenggaraan Pemilukada Gubernur dan Wakil Gubernur Relatif Lebih Tinggi}

Pendanaan yang dimaksud disini adalah pendanaan baik yang dikeluarkan oleh calonpeserta pemilukada gubernur dan wakil gubernur dan pendanaan yang dikeluarkan oleh pemerintah. Pemilukada gubernur dan wakil gubernur dalam era liberalisasi politik dengan kekuatan partai politik yang masih dominan, memungkinkan sekali yang bisa bertempur disana adalah mereka yang memiliki kapital ekonomi dan politik yang kuat. Para pengusaha yang sekaligus dekat dengan partai politik, atau para incumbent yang kaya, adalah yang paling besar dalam mendapatkan peluang masuk dalam bursa pencalonan pemilukada. Betapa tidak, di daerah tingkat provinsi wilayah teritorial yang menghubungkan antara kabupaten/kota sangatlah jauh sehingga membutuhkan dana yang cukup besar untuk melaksanakan kegiatan sosialisasi terhadap pencalonan. Jadi, bukan figur-figur yang kompeten dalam kacamata kepemimpinan modern yang bisa masuk disana, tetapi justru mereka yang berkategori orang-orang kaya yang berpeluang besar ikut masuk dalam bursa pemilukada gubernur dan wakil gubernur.

Pendanaan dari pemerintahan dengan melaksanakan pemilukada gubernur dan wakil gubernur juga bukan jumlah yang sedikit. Pemilukada gubernur dan wakil gubernur yang telah dilaksanakan di Provinsi DKI Jakarta dengan dua kali putaran sejumlah Rp 253 Miliar . Menurut Sekretaris Kesatuan Bangsa dan Politik (Kesbangpol) DKI Jakarta, M. Arief Amien, mengungkapkan anggaran itu digunakan untuk pelaksanaan putaran pertama Rp 193,5 Miliar dan putaran kedua Rp 59,8 Miliar . ${ }^{16}$ Selanjutnya, beberapa daerah di Indonesia banyak yang akan melaksanakan pemilukada gubernur dan wakil gubernur. Di antara daerah yang akan melaksanakan pemilukada gubernur dan wakil gubernur adalah Provinsi Sulawesi Selatan, Sumatera Utara, Jawa Timur, dan lain sebagainya. pemilihan gubernur dan wakil gubernur pada Provinsi Sumatera Utara pemerintah menganggarkan dana sekitar Rp 639 Miliar dari APBD 2013, ${ }^{17}$ dan dana pemilihan gubernur dan wakil gubernur ini dialokasikan pada KPU Sumut sebesar Rp 482 Miliar, Panwas sebesar Rp 70 Miliar serta pengamanan oleh Polda Sumut dan TNI

\footnotetext{
${ }^{15} \mathrm{http}: / /$ www.Google. com/...Op.cit.

${ }_{16} \mathrm{http} / / /$ metro.news. viva.co.id/news/read/264577-Pemilihan-Gubernur-DKI-Telan-BiayaRp-253-m. ( Terakhir diakses pada Tanggal 19 Januari 2013).

${ }^{17} \mathrm{http} / / /$ www.tribunnews.com/2012/12/03/Sumut-Pangkas-Dana-Daerah-untuk-PemilihanGubernur.( Terakhir diakses pada Tanggal 19 Januari 2013).
} 
sebesar Rp 87 Miliar ${ }^{18}$ Sedangkan pemilihan gubernur dan wakil gubernur Jawa Timur yang akan dilaksanakan pada Tahun 2013 pemerintah menganggarkan dana sebesar Rp 943 Miliar yang Hampir Rp 1 Triliun. ${ }^{19}$

\section{b. Membuka Kemungkinan Konflik Elit dan Massa}

Pemilukada langsung memang dapat melahirkan problem kelembagaan baru yang disuatu titik nanti bisa menodai demokrasi lokal. Itu terjadi karena kepala daerah yang dihasilkan dari sistem pilkada langsung, posisinya akan semakin kuat, begitu pula dalam hal legitimasinya. Bukan penelitian dibeberapa negara Amerika Latin membuktikan bahwa ketika posisi eksekutif menjadi semakin kuat, justru potensial sekali kembali melahirkan otoritarianisme. Itu terjadi karena eksekutif merasa memiliki legitimasi yang sama-sama kuat dengan DPRD, sementara eksekutif tidak bisa dijatuhkan parlemen. Itu sebabnya, menjaga keseimbangan agar otoritarianisme tidak lahir pasca pilkada mesti menjadi kewajiban bagi siapapun yang menjadi bagian dari kekuatan masyarakat sipil. ${ }^{20}$

Selain itu, pemilukada menjadikan sebagai alat pemecah belah terhadap budaya dan hubungan masyarakat lokal. Betapa tidak, masyarakat telah didoktrin oleh masing-masing tim suskses para kandidat calon kepala daerah dan wakil kepala daerah untuk memilih mereka dengan diberikan imbalan. Contoh kasus dalam pemilihan Gubernur dan Wakil Gubernur Papua antara Abraham O Ataruri dan yang kalah Dominggus mandacanOrigenes. Konflik yang terjadi antara masing-masing pendukung pasangan calon Gubernur dan Wakil Gubernur Papua, di mana dengan cara membakar rumah pribadi pasangan yang memenangkan pemilukada. Hal inilah yang seharusnya dihindarkan dalam menjaga kesatuan daerah setempat.

\section{c. Aktivitas Rakyat Terganggu Khususnya pada Saat Kampanye}

Kampanye merupakan bagian dari proses di dalam tahapan pemilukada dalam mencari massa untuk meraup suara dari masyarakat. Sebagian rakyat memiliki prespektif yang berbeda di dalam menanggapi tahapan pemilukada tersebut. Namun, sebagian besar kalangan masyarakat merasa terganggu, di mana mereka melakukan kampanye tersebut yang pada intinya menggangu aktivitas masyarakat. Yaitu, dengan melakukan kampanye di jalan-jalan, kemudian menempelkan stiker-stiker gambar para calon gubernur dan wakil gubernur di rumah-rumah warga sehingga akan menimbulkan kekotoran.

\footnotetext{
${ }^{18}$ Ibid.

19 http://bappeda.jati mprov.go.id/2012/10/17/Dana-Pilgub-Jatim-Rp-1-Triliun/ (Terakhir diakses pada Tanggal 19 Januari 2013)

${ }^{20}$ Ibid.
} 


\section{d. Masyarakat Tidak Menggunakan Hak Suaranya}

Output dari kampanye pada dasarnya ditujukan untuk mengajak masyarakat umumnya menggunakan hak pilihnya untuk kemudian memilih calon Gubernur dan Wakil Gubernur yang diusung salah satu partai tertentu. Dalam pemilu juga tidak lepas dari masalah golput, yaitu keadaan di mana para anggota masyarakat yang memiliki hak pilih tidak menggunakan hak pilihnya karena berbagai alasan, di antaranya: ${ }^{21}$

1) faktor tuntutan ekonomi (contoh: supir bus yang demi memenuhi kebutuhan hidupnya terpaksa tidak memilih dalam pemilu karena harus bekerja);

2) faktor politik (contoh: bagi orang yang memiliki ideologi apatis);

3) golput dijadikan sebagai ideologi; dan

4) karena faktor administrasi yang kurang baik, sehingga menyebabkan orang tidak terdaftar dan tidak bisa menggunakan hak pilihnya.

Partisipasi masyarakat dalam menggunakan hak pilihnya terhadap proses pemilukada khususnya gubernur dan wakil gubernur adalah salah satu bagian hal yang terpenting dalam suskses atau tidaknya proses pemilukada. Oleh sebab itu, dalam proses pemilukada salah satu kelemahan yang harus diperhatikan adalah masyarakat yang tidak menggunakan hak pilihnya.

\section{Beberapa Upaya yang Perlu Dilakukan untuk Memperbaiki Kelemahan Pemilihan Gubernur dan Wakil Gubernur yang Sesuai dengan Perkembangan Pemerintahan Daerah Saat Ini.}

Untuk menanggulangi permasalahan yang timbul dalam pemilukada bisa ditempuh dengan cara sebagai berikut:

\section{a. Optimalisasi Check and Balances antar Kepala Daerah dengan Dewan Perwakilan Daerah.}

Optimalisasi terhadap sistem check and balances antara gubernur sebagai kepala daerah (Executive) dengan DPRD (Legislative) perlu disinergiskan kembali. Mengingat kedua lembaga tersebut yaitu antara gubernur sebagai eksekutif dan DPRD sebagai legislative merupakan penyelenggara pemerintahan dalam sistem pemerintahan didaerah. Di mana disebutkan dalam Pasal 19 ayat (2) Undang-Undang Nomor 32 Tahun 2004 tentang Pemerintahan Daerah yaitu "penyelenggaraan pemerintahan daerah adalah pemerintah daerah dan DPRD”.

Ketika hubungan tersebut dipelihara dengan baik, baik melalui komunikasi kelembagaan, saling mengawal, dan mengimbangi dengan

\footnotetext{
${ }^{21}$ http://Shubuha.blog.fisip.uns.ac.id/2010/12/05/Pemilukada-Sebagai-Cerminan-Demokrasidi-Tingkat- Lokal/ ( Terakhir dikunjungi, Minggu,13 Januari 2013).
} 
sepenuhnya mengingat masing-masing tugas dari kepala daerah dan DPRD. Maka, gubernur di dalam menjalankan program-program pemerintahannya yang prorakyat akan mendapat dukungan penuh oleh DPRD dan juga perlu mengambil inisiatif dan langkah strategis dalam memanfaatkan wewenangnya untuk menjalankan program-program pembangunan di daerah secara efektif dan optimal.

Dalam pola yang seimbang antara legislatif dan eksekutif itu pula dibangun hubungan antara legislatif dan eksekutif daerah dalam melaksanakan demokrasi lokal. Melalui keseimbangan kekuasaan antara legislatif dan eksekutif di daerah diharapkan mekanisme check and balances di tingkat lokal dapat betul-betul direalisasikan dalam rangka memperjuangkan kepentingan rakyat sebagai pemilik kedaulatan tertinggi didaerah. ${ }^{22}$ Ini diawali dengan proses pemilihan pemimpin publik di daerah tidak saja menyangkut proses pemilihan kepala daerah, namun juga menyangkut keterwakilan rakyat di lembaga perwakilan, sejauh mana lembaga perwakilan tersebut mengartikulasikan, mengagresikan, serta memperjuangkan kepentingan rakyat termasuk dalam proses pembuatan peraturan daerah.

\section{b. Pembatasan Dana Kampanye Pemilukada}

Demokrasi yang mahal maka akan menghasilkan kualitas demokrasi yang baik pula, jadi menurut penulis hal ini bukan menjadi alasan yang berarti di dalam penerapan sistem pemilihan gubernur secara langsung oleh rakyat. Betapa tidak, dengan adanya wacana dari pemerintah pusat dengan pemilihan gubernur dan wakil gubernur dipilih kembali oleh DPRD maka sangat tidak kompatimbel ketika format yang lama diterapkan kembali didalam pemilihan gubernur dan wakil gubernur. Ketika ada cara lain untuk mengatasi persoalan demokrasi yang mahal mengapa kita harus pesimis dengan wacana didalam draft Rancangan Undang-Undang (RUU) mengembalikan pemilihan gubernur dan wakil gubernur dipilih oleh DPRD. Beberapa solusi yang diterapkan terhadap demokrasi yang mahal, yaitu dengan adanya pembatasan dana kampanye bagi para calon gubernur dan wakil gubernur yang akan berkompetisi. Dengan demikian maka satu sama lain akan memiliki model yang sama dan tidak boleh melebihi batas yang ditentukan dalam kampanye.

Aturan mengenai pembatasan jumlah sumbangan bagi para calon kepala daerah memang telah diatur didalam Peraturan Pemerintah Nomor 6 Tahun 2005 Pasal 65 Ayat (3) dengan tegas disebutkan bahwa sumbangan dana kampanye dari perseorangan dilarang melebihi Rp 50.000.000,00

\footnotetext{
22 http://www.kursikayu.com/2012/03/Demokrasi-Indonesia-Antara-Check-and-Balances. ht $\mathrm{ml}$ (terakhir diakses pada Tanggal 22 Januari 2013).
} 
(lima puluh juta rupiah) dan dari badan hukum swasta dilarang melebihi Rp $350.000 .000,00$ (tiga ratus lima puluh juta rupiah). Namun pada ayat (4) disebutkan bahwa pasangan calon dapat menerima dan/atau menyetujui pembiayaan bukan dalam bentuk uang secara langsung untuk kegiatan kampanye. $^{23}$ Namun demikian, sampai sekarang tidak ada aturan yang mengatur mengenai batasan dana kampanye bagi para calon gubernur dan wakil gubernur.

\section{c. Meningkatkan Kesadaran untuk Pendidikan Politik Masyarakat dalam Berpartisipasi terhadap Proses Jalannya Pemilukada}

Pemilu tidak sekedar persoalan memilih dan dipilih, namun merupakan salah satu wahana pendidikan politik untuk warga negara. Setiap proses kampanye adalah merupakan pendidikan politik bagi masyarakat. Pendidikan politik menurut alfian (1986:235) merupakan usaha yang sadar untuk merubah sosialisasi politik masyarakat sehingga mereka memahami dan benar-benar menghayati nilai-nilai yang terkandung dalam suatu sistem politik yang ideal yang hendak dibangun. ${ }^{24}$

Kemudian menurut Syafrudin, aktifitas yang bertujuan untuk membentuk dan menumbuhkan orientasi politik pada individu, meliputi keyakinan konsep yang muatan politis, loyalitas dan perasaan politik, serta pengetahuan dan wawasan politik yang menyebabkan seseorang memiliki kesadaraan terhadap persoalan politik dan sikap politik. ${ }^{25}$

Di samping itu, juga untuk setiap individu memberikan partisipasi politik yang aktif dimasyarakatnya. Pendidikan politik, aktivitas yang terus berlangsung di dalam kehidupan manusia dan itu tidak dapat terwujud kecuali di dalam sebuah masyarakat yang demokratis.

Dengan demikian pendidikan politik memiliki tiga tujuan: ${ }^{26}$

1) membentuk kepribadian politik;

2) kesadaran politik; dan

3) membentuk kemampuan dalam berpartisipasi politik.

Ini semua bertujuan agar para masyarakat menjadi partisipan dalam bentuk yang positif. ${ }^{27}$ Pembentukan kepribadian dapat dilakukan melalui metode secara tidak langsung yaitu melalui sosialisai dan pelatihan serta metode yang bersifat langsung melalui institusi pendidikan. Jika hal-hal tersebut dapat terbentuk dalam jiwa setiap warga negara yang ditegakan

\footnotetext{
${ }^{23}$ Leo Agustino, Pilkada dan Dinamika Politiklokal, (Yogyakarta: Pustaka Pelajar, 2009), hlm.133.

${ }^{24}$ Marita Ahdiyana, "Pemilu Sebagai Wahana Pendidikan Politik", makalah disampaikan pada Pidato Ilmiah,STIAAAN Yogyakarta,13 Juni 2009. hlm.3.

${ }^{25}$ Ibid.

${ }^{26}$ Ibid.

${ }^{27}$ Ibid.
} 
dengan pilar-pilar ideologi, spiritual, moral, dan intelektual. Maka, bangsa ini diharapkan menjadi bangsa yang berkarakter dan dapat mengantar warga Indonesia menjadi bangsa yang maju dan besar.

Dengan demikian, berdemokrasi dengan menggunakan suara langsung oleh rakyat sejatinya tidak akan merugikan masyarakat. Apalagi dengan menggunakan hak suaranya untuk pemilihan gubernur dan wakil gubernur adalah merupakan warga yang baik dalam turut menyukseskan serangkaian kegiatan pemilukada gubernur dan wakil gubernur.

\section{d. Penegakan Aturan Pemilukada yang Konsisten.}

Dalam berdemokrasi salah satu syarat pokoknya adalah adanya sitem pemilihan umum (pemilu) yang jujur dan adil. Begitu pula dengan berdemokrasi di daerah, yaitu ditandai dengan adanya pemilihan umum kepala daerah. Pemilihan kepala daerah dalam hal ini, gubernur dan wakil gubernur yang dilakukan dengan jujur dan adil tentunya dapat dicapai apabila tersedia perangkat hukum yang mengatur proses pelaksanaan pemilukada di daerah. Sekaligus melindungi para penyelenggara, kandidat, pemilih, pemantau, dan warga negara pada umumnya dari ketakutan, intimidasi, kekerasan, penyuapan, penipuan, dan berbagai praktek curang lainnya yang tentunya akan mempengaruhi hasil pemilihan tersebut sehingga berbagai cara dilakukan oleh kandidat yang bertanding supaya menang. ${ }^{28}$ Ada berbagai acuan dan rujukan untuk mengategorikan bahwa suatu kegiatan atau tindakan adalah pelanggaran yaitu dengan berbagai UndangUndang kepemiluan yang ada di Indonesia. Undang-Undang Kepemiluan tersebut antara lain Undang-Undang No. 15 Tahun 2011 mengenai Penyelenggara Pemilu, Undang-Undang No. 2 Tahun 2011 mengenai Partai Politik, Undang- Undang No. 10 Tahun 2008 mengenai Pemilu Legislatif (sedang dibahas di DPR dan diperkirakan selesai bulan April 2012 ini), dan sejumlah peraturan KPU. ${ }^{29}$ berikut: ${ }^{30}$

Adapun pelanggaran pemilukada dapat dikategorikan sebagai

1) pelanggaran terhadap peraturan Pemilu dan Pemilukada yang pengaruhnya tidak bisa diukur signifikansinya dengan hasil Pemilu dan Pemilukada. Misalnya: baliho, tanda gambar dalam sosialisasi, pemberian hadiah ketika sosialisasi, dan lain-lain;

\footnotetext{
${ }^{28}$ Penulis adalah Pengurus Komite Independen Pemantau Pemilu (KIPP) Indonesia, Divisi Hubungan Luar Negeri dan Pemantau Pemilu Internasional http://politik.kompasiana.com/2012/04/07/Tiga-Pelanggaran-Pemilukada-453040. html. (Terakhir diakses22 Januari2013).

${ }^{29}$ Ibid.

${ }^{30}$ Ibid.
} 
2) pelanggaran serius terhadap prinsip-prinsip dasar pemilukada yang luber dan jurdil. Misalnya: adanya money politics, dan ikut sertanya PNS dan birokrasi baik sebagai tim sukses, ikut serta dalam kampanye hingga sosialisasi mengenai calon tertentu saja; dan

3) pelanggaran serius terhadap hak konstitusional bakal pasangan calon atau pasangan calon sehingga mengakibatkan bakal pasangan calon kehilangan hak konstitusionalnya. Contoh lain adalah menakut-nakuti atau mengintimidasi kandidat saingan agar tidak ikut berkompetisi atau menjadi calon.

Dari kategori pengelompokan jenis pelanggaran pemilukada merupakan suatu hal kekinian yang sering terjadi didalam proses pemilukada. Hal ini tentunya memudahkan untuk rakyat sebagai pemilih untuk melaporkan kegiatan atau tindakan yang mengarah ke arah pelanggaran jenis apapun (jika belum paham atau sulit mengkategorikan jenis pelanggaran) kepada PPL (Pengawas Pemilu Lapangan yang bergerak di level kelurahan), Panwascam (Pengawas Pemilu dilevel Kecamatan), Panwas (Pengawas Pemilu dilevel Kabupaten dan Provinsi), atau ke Bawaslu (Badan Pengawas Pemilu level Nasional).

\section{e. Memberdayakan Pemilukada Yang Langsung, Umum, Bebas, Jujur, dan Adil.}

Salah satu cara untuk melaksanakan pemilukada yang langsung, umum, bebas, rahasia, jujur, dan adil adalah dengan cara hubungan yang relevan antara penyelenggara, pemilih (masyarakat) dan pengawas pemilukada. Hal ini ditujukan untuk menciptakan suatu bentuk pemilukada yang transparansi dan akuntabilitas. Hal ini dilakukan dengan saling terjalin komunikasi yang baik, antara penyelenggara, pemilih (masyarakat) dan pengawas pemilukada dalam menyukseskan proses pemilukada tersebut.

Asas penyelenggaraan pemilukada adalah sama dengan asas pemilihan umum yaitu langsung, umum, bebas, jujur, rahasia, dan adil. Berdasarkan Pasal 56 ayat (1) Undang- Undang Nomor 32 Tahun 2004, yaitu kepala daerah dan wakil kepala daerah dipilih dalam satu pasangan calon yang dilaksanakan secara demokratis berdasarkan asas langsung, umum, bebas, rahasia, jujur, dan adil. Asas ini dianut didalam pelaksanaan Pemilukada secara langsung. Asas pemilihan umum sama dengan asas pemilihan kepala daerah yang tercantum dalam Undang-Undang Nomor 10 Tahun 2008 tentang Pemilihan Umum anggota DPR, DPD, dan DPRD serta berdasarkan Undang-Undang Nomor 42 Tahun 2008 tentang pemilihan 
presiden dan wakil presiden juga sama-sama menerapkan asas langsung, umum, bebas, rahasia, jujur, dan adil. ${ }^{31}$

Berdasarkan Pasal 2 Undang-Undang Nomor 10 Tahun 2008 tentang pemilihan DPR, DPD, dan DPRD, penyelenggaraan pemilu yang demokratis harus memenuhi asas-asas pemilu yaitu langsung, umum, bebas, rahasia, jujur, dan adil yaitu:

1) asas langsung, berarti rakyat sebagai pemilih memberikan suaranya secara langsung sesuai dengan kehendak nuraninya, tanpa perantara;

2) asas umum, berarti berlaku secara menyeluruh bagi semua warga negara, tanpa diskriminasi;

3) asas bebas, berarti setiap warga negara bebas menentukan pilihan berdasarkan hati nuraninya dalam melaksanakan hak pilihnya setiap warga negara dijamin keamanannya dari pengaruh, tekanan, dan paksaan dari siapapun dan dengan cara apapun;

4) asas rahasia, berarti dalam memberikan suaranya, kerahasiaan suara pemilih terhadap pilihannya dijamin tidak akan diketahui oleh pihak manapun dan dengan jalan apapun;

5) asas jujur, berarti dalam penyelenggaraan pemilu, setiap penyelenggara pemilu, aparat pemerintah, peserta pemilu, pengawas pemilu, pemantau pemilu, pemilih serta semua pihak yang terkait harus bersikap dan bertindak jujur sesuai dengan peraturan perundang-undangan; dan

6) asas adil, berarti dalam penyelenggaraan pemilu, setiap pemilih dan maupun partai politik peserta pemilu mendapat perlakuan yang sama serta bebas dari kecurangan pihak manapun.

Ketika di dalam melaksanakan proses pemilukada gubernur dan wakil gubernur benar-benar menerapkan asas-asas tersebut, maka kesuksesanlah yang didapatkan. Namun sebaliknya, ketika asas-asas tersebut tidak berhasil diterapkan di dalam proses pemilukada bukan tidak mungkin kerusuhan dan kekacauan yang terjadi sehingga tidaklah sukses terhadap pelaksanaan pemilukada gubernur dan wakil gubernur tersebut. Penyelenggaraan pemilukada secara langsung, umum, bebas, rahasia, jujur, dan adil hanya dapat terwujud apabila dilaksanakan oleh penyelenggara pemilihan umum yang mempunyai integritas, profesionalitas, dan akuntabilitas.

31 Brownson, Tinjauan Yuridis Peralihan Pemilihan Kepala Daerah dari Rezim Pemerintahan Daerah ke Rezim Pemilihan Umum, Skripsi, (Pekanbaru: Program Sarjana Universitas riau, 2011), hlm.40. 


\section{Penutup}

\section{Kesimpulan}

a. Adapun latar belakang diterapkannya pemilihan gubernur dan wakil gubernur secara langsung oleh rakyat dapat ditinjau secara filosofis, sosiologis, dan yuridis.

1) pertama, secara filosofis kita bisa melihat bahwa dorongan untuk melaksanakan pemilihan kepala daerah secara langsung ini antar lain karena mekanisme demokrasi secara tidak langsung belum menjamin terakomodasinya aspirasi rakyat dalam memilih calon pemimpinnya;

2) kedua, secara sosiologis pemilihan kepala daerah dalam hal ini gubernur dan wakil gubernur secara langsung oleh rakyat merupakan perwujudan pengembalian "hak-hak dasar" rakyat dalam memilih pemimpin di daerah; dan

3) ketiga, pemilukada secara langsung sesungguhnya sudah diintrodusir dalam produk hukum yang mengatur pemerintahan didaerah jauh sebelum pembentukan Undang-Undang Nomor 32 Tahun 2004 dan Undang-Undang Nomor 22 Tahun 2007. Dalam Pasal 23 UndangUndang Nomor 1 Tahun 1957 tentang Pokok-Pokok Pemerintahan Daerah ditegaskan, "Kepala Daerah yang karena jabatannya adalah ketua dan anggota Dewan Pemerintahan Daerah (DPD) yang berfungsi menjalankan roda pemerintahan dipilih menurut Undang-undang khusus yang akan ditetapkan kemudian".

b. Beberapa kelebihan dan kelemahan terhadap praktek pemilukada langsung. Adapun beberapa kelebihan dan kelemahan pemilihan gubernur dan wakil gubernur secara langsung di dalam Undang-Undang Nomor 32 Tahun 2004 tentang Pemerintahan Daerah adalah sebagai berikut; Pemilukada langsung merupakan jawaban atas tuntutan aspirasi rakyat yang merupakan ajang pendidikan politik, check and balances antara lembaga legislatif dan eksekutif dapat lebih berjalan seimbang, pemilukada langsung sebagai sarana untuk memperkuat otonomi daerah, pemilukada langsung merupakan sarana penting bagi proses kaderisasi kepemimpinan nasional, kemudian pemilukada langsung merupakan suatu langkah yang strategis dalam rangka memperluas, memperdalam, dan meningkatkan kualitas demokrasi. Selanjutnya adapun beberapa kelemahannya sebagai berikut; dana yang dibutuhkan dalam penyelenggaraan pemilukada gubernur dan wakil gubernur relatif lebih tinggi, membuka kemungkinan konflik elit dan massa, aktivitas rakyat terganggu khususnya pada saat kampanye, masyarakat tidak menggunakan hak suaranya.

c. Adapun bentuk upaya yang perlu dilakukan untuk memperbaiki kelemahan pemilihan gubernur dan wakil gubernur yang sesuai dengan perkembangan pemerintahan daerah saat ini adalah sebagai berikut; 
optimalisasi check and balances antar kepala daerah dengan dewan perwakilan daerah, pembaharuan dengan pembatasan dana kampanye pemilukada, meningkatkan kesadaran politik masyarakat serta kontrol pemerintahan terhadap proses jalannya pemilukada, penegakan aturan pemilukada yang konsisten dan memberdayakan pemilukada yang langsung, umum, bebas, jujur dan adil.

\section{Saran}

a. Disarankan agar pemerintah pusat bersama legislatif mendesain suatu Rancangan Undang-Undang tentang pemilukada terhadap pemilihan gubernur dan wakil gubernur yang pada intinya tetap dipilih secara langsung oleh rakyat. Selanjutnya membuat Rancangan Undang-undang terhadap pembatasan dana kampanye agar meminimalisir biaya kampanye bagi para calon yang bersaing supaya lebih adil dan memungkinkan tidak terjadinya pengembalian terhadap dana kampanye bagi calon terpilih.

b. KPU harus bekerja lebih profesional dengan menerapkan prinsip transparan dan partisipatif yaitu dengan sejak awal proses pelaksanaan pemilukada mereka melibatkan semua pihak yang terkait dengan penyelenggaraan pemilukada tersebut, baik oleh PERS, LSM, ORMAS, dan masyarakat pada umumnya.

c. Kepada seluruh pihak yang terkait dengan pengamanan dan penegakan aturan pelaksanaan pemilukada baik dari KPU, BAWASLU, dan POLRI agar bertanggung jawab penuh dalam melaksanakan tugas-tugasnnya, artinya untuk menindak dan memberikan sanksi yang tegas terhadap pelanggaran-pelanggaran pemilukada. Baik yang bersifat administratif maupun pidana dan bahkan sampai dengan pelanggaran-pelanggaran yang sangat kecil sehingga terciptanya asas dari pemilukada yang langsung, umum, bebas, rahasia, jujur, dan adil.

\section{Daftar Pustaka}

\section{A. Buku}

Agustino, Leo, 2009. Pilkada dan dinamika politik lokal, Yogyakarta: Pustaka Pelajar.

Pramusinto, Agus, Erwan Agus Purwanto, 2009. Reformasi Birokrasi, Kepemimpinan dan Pelayanan PublikKajian tentang pelaksanaan otonomi Daerah di Indoensia, Yogyakarta: Gava Media. 
Prihatmoko, Joko J., 2005. Pemilihan Kepala Daerah Langsung; Filosofis, Sistem, dan Problema Penerapan di Indonesia, Yogyakarta: Pustaka Pelajar.

Sentosa, Daniel S., 2005. Pilkada Langsung, Jakarta: Media Pressindo.

Suharizal, 2011, Pemilukada Regulasi Dinamika, dan Konsep Mendatang, Jakarta: PT Raja Grafindo Persada.

\section{B. Jurnal/Kamus/Makalah}

Brownson, 2011, Tinjauan Yuridis Peralihan Pemilihan Kepala Daerah dari Rezim Pemerintahan Daerah ke Rezim Pemilihan Umum. Skripsi, Pekanbaru: Program Sarjana Universitas riau.

Simamora, Jhanpatar, 2011, Eksistensi Pemilukada dalam Rangka Mewujudkan Pemerintahan Daerah yang Demokratis, Jurnal Mimbar Hukum Volume, Fakultas Hukum Universitas Gadjah Mada Yogyakarta, 23 No. 1 Februari.

Ahdiyana, Marita, 2009, Pemilu Sebagai Wahana Pendidikan Politik, makalah disampaikan pada Pidato Ilmiah, STIA AAN Yogyakarta, 13 juni.

\section{Peraturan Perundang-undangan}

Undang-Undang Nomor 32 Tahun 2004 tentang Pemerintahan Daerah.

Undang-Undang Nomor 22 Tahun 2007 tentang Penyelenggaraan Pemilihan Umum.

Undang- Undang Nomor 12 tahun 2008 tentang Perubahan kedua Atas Undang-UndangNomor 32 Tahun 2004 tentang Pemerintah Daerah

\section{Website}

http://politik.kompasiana.com/2012/04/07/Tiga-Pelanggaran-Pemilukada453040.html.(Terakhir diakses 22 Januari 2013).

http://blogspotcorner.blogspot.com/2012/09/Hasil-Final-Perolehan-SuaraPilkada- DKI.html?=1(terakhir diakses pada Tanggal 22 Januari 2013). http://www.kursikayu.com/2012/03/Demokrasi-IndonesiaAntara-Check-and-Balances.html (terakhir diakses pada Tanggal 22 Januari 2013).

http://Shubuha.blog.fisip.uns.ac.id/2010/12/05/Pemilukada-SebagaiCerminan-Demokrasi- di-Tingkat-Lokal/ (Terakhir dikunjungi, Minggu, 13 Januari 2013).

http://metro.news.viva.co.id/news/read/264577-Pemilihan-Gubernur-DKITelan-Biaya-Rp-253-m. (Terakhir diakses pada Tanggal 19 Januari 2013). 
http://www.tribunnews.com/2012/12/03/Sumut-Pangkas-Dana-Daerahuntuk-Pemilihan- Gubernur.(Terakhir diakses pada Tanggal 19 Januari 2013).

http://bappeda.jatimprov.go.id/2012/10/17/Dana-Pilgub-Jatim-Rp-1Triliun/(Terakhir diakses pada Tanggal 19 Januari 2013).

http://masnurmarzuki.blogspot.com/2011/12/Pemisahan-Pekuasaan-danPrinsip- Checks.html9 (Terakhir diakses Tanggal 22 Januari 2013).

http: // www. Google.com/ search? ie=UTF8\& Sourceid=navclient\& gfns $=1 \& \mathrm{q}=$ Makalah+tentang+Pilkada(Terakhir diakses pada Tanggal 29 Desember 2012).

http://wwwPolitikIndonesia.com/m/index.php?ctn= politik\&i=29840. (Terakhir diakses Sabtu 15 Desember 2012). 